\title{
Paul de Saint Robert: Sciences and Interdisciplinary Culture in the 19th Century
}

\author{
Federica Maffioli, Gianfranco Medici \\ Cultural Association Tower of Count Paolo Ballada de Saint Robert, Castagnole delle Lanze, Italy \\ Email: federicamaffioliarchitetto@yahoo.it, gian.medici@alice.it
}

Received 1 September 2014; revised 1 October 2014; accepted 7 October 2014

Copyright (C) 2014 by authors and Scientific Research Publishing Inc.

This work is licensed under the Creative Commons Attribution International License (CC BY). http://creativecommons.org/licenses/by/4.0/

\section{(c) (i) Open Access}

\begin{abstract}
The Count Paul Ballada de Saint Robert (1815-1888) was an Italian scientist and important promoter of scientific culture, he succeeded in combining pure and applied science, art and social interests into one of the most elevated synthesis. Based on previous works published at the SISFA 2012 (Maffioli \& Medici, 2013: pp. 313-319; Medici \& Maffioli, 2013: pp. 329-336) in this paper we propose two of his many writings as demonstration of interdisciplinary of his studies: the first part is about the conclusions of Saint Robert concerning the retreat of glaciers, while the second part is about the Saint Robert's scientific approach and explanation of the true meaning of the verses 22.24 of the I chant of Dante's Purgatory.
\end{abstract}

\section{Keywords}

Adhémar, Alps, Allegorical, Astronomy, Chant I, Commentators, Dante, Equinoxes, History of Climate Change, Glaciers, Marsh, Milankovitch, Paul de Saint Robert, Precession, Purgatory

\section{Recedings of the Glaciers}

\subsection{A Short Introduction}

An increase of scientific studies on glaciers started only in the middle of 19th century. The interest was great and for the Italian Alps of Piedmont was involved in scientists, geologists and glaciers scholars. In Italy the scientific approach to the glaciers observation was driven by the rise of Italian alpinism where many of these scholars belonged (Malaroda, 1995). In 1927 Federico Sacco (1864-1948), President of the Committee of Glaciology, collected and ordered all the main glaciology studies, where next to important scholars he mentioned the 
note of Saint Robert ${ }^{1}$ defined as a bearer of good observations on glaciology (Sacco, 1927). In 1930 the Saint Robert's note was listed in the bibliography of the Bulletin of the Italian Glaciological Committee that brings together all the major scientific studies on glaciers (Capello, 1930).

\subsection{Why Saint Robert Wrote This Note}

In the paper presented at the Royal Academy of Lincei on 2 December 1883, published also in the Alpine Jour$\mathrm{nal}^{2}$, Saint Robert submitted observations to the Note entitled On the temperature corresponding to the glacial period (Blaserna, 1883-1884a, 1883-1884b, 1882-1883) presented by Pietro Blaserna (1836-1918).

In a letter ${ }^{3}$, dated 20 November 1883, Saint Robert manifested to his friend Quintino Sella (1827-1884), President of the Royal Academy of Lincei of Rome, the intention to submit a paper about glaciers to integrate the theories exposed by professor Blaserna. This caused some discontent in Blaserna who soon answered in two papers published at the Royal Academy of Lincei (Ivi). It did not follow an official response from Saint Robert probably because he was already sick and tired.

The interest of Saint Robert for a subject far to his expertise is due to his work as scientist mountaineer who led him directly to practice and study glaciers. For example, during the ascent to Mount Ciamarella he wrote: "Being the technical alpine language yet to be formed, I make bold to propose the word rima to indicate the cracks formed in glaciers, to which the French people give the name crevasses [...]" (Saint Robert, 1867: p. 247). It's probable that Saint Robert, in the formulation of his theory, was influenced by George Perkins Marsh (1801-1882), USA ambassador in Turin in the early years of Kingdom of Italy and ante litteram ecologist, author of the book "Man and nature” translated also into Italian ${ }^{4}$ (Perkins Marsh, 1870).

\subsection{Blaserna's Theory}

In extreme synthesis: Pietro Blaserna, through his mathematical studies and the collection and processing of weather data, concluded that the maximum development of European glaciers corresponded to a temperature higher than current one (Blaserna, 1882) and agreeing with the theories of Auguste Arthur de la Rive (18011873), John Tyndall (1820-1893) and Antonio Stoppani (1824-1891), he said that the temperature of Europe during the Ice Age was higher than current (De Marchi, 1911).

\subsection{Saint Robert's Theory}

In the first observation to Blaserna's theory, Saint Robert indicates that Blaserna does not consider the decrease of temperature to explain ice age (Saint Robert, 1883-1884). Saint Robert points out that there are evident traces of glaciers in places where currently there are no more, as for example to the Gran Sasso of Italy. It is impossible, as Blaserna instead supposed, that the increase of temperature could make possible the return of these glaciers, because in this condition the perennial snowline rises and the condensing surface disappears. The traces of past glaciers show that, in the ice age, the perennial snowline was much lower than actual and this was possible only thanks to a lower temperature or at least to a lower summer temperature. Saint Robert concludes that atmospheric temperature was lower in the ice age and not higher, as Blaserna supposed.

\footnotetext{
${ }^{1}$ The count Paolo Ballada de Saint Robert was born in Verzuolo, Italy on the 10th June 1815. As very young boy, he entered the Military Academy of Turin becoming soon lieutenant of artillery, and afterwards professor of ballistic at the Military School of Turin. At 45 years he left the Army for devoting himself to the study of physical and military sciences. He was a member of the Reale Accademia delle Scienze of Turin, the Reale Accademia dei Lincei of Rome and of the Società (Academy) Italiana called XL (forty). His life was dedicated to technicalscientific studies: Ballistics, Artillery, Mechanic, Hypsometry, Thermodynamic and natural studies (Saint Robert, 1872-1874). His studies of Thermodynamic were very important (Drago, 1993; Pisano, 2007; Redondi, 1974): he was the first in Italy to write about Sadi Carnot (Saint Robert, 1868-1869) and his work Principes de Thermodynamique (Saint Robert, 1865; Saint Robert, 1870) was adopted as text book in the most important Universities in Europe. Raffaele Pisano describes Saint Robert as an important promoter of scientific culture, scholar of military technology among the most distinguished of his time, he succeeded in combining pure and applied science, art and social interests into one of the most elevated synthesis (Pisano, 2014; Pisano, 2013; Gillispie \& Pisano, 2014; Pisano, 2007). As a passionate mountaineer, he did many alpine excursions and he was the main promoter and organizer of the first Italian ascent to mount Monviso in 1863 with his friend Quintino Sella, and contributed to the foundation of the Italian Alpine Club in the same year (Crivellaro, 1998); he was also Honorary Member of the Alpine Club of London and intimate friend with William Mathews, John Ball and Francis Fox Tuckett. He retired in Castagnole delle Lanze in 1878 until 1884. He died in Turin in 1888.

${ }^{2}$ Alpine Journal, n. 85, vol. XII, August 1884, pp. 134-136.

${ }^{3}$ Fondo Carte Quintino Sella, letter n. 885, Sella Foundation, Biella.

${ }^{4}$ We know for sure that this book was part of his personal library, as found in the list of Saint Robert's books donated to Biblioteca Civica di Torino.
} 
The second observation it's about the significant retreat of glaciers during the XIXth century. According to the theory of Prof. Blaserna such receding corresponded to a decrease in temperature. Saint Robert explains how, not only the average annual temperature has not changed much in recent years, but remains mostly constant from 33 centuries.

What is the mistake of Blaserna's theory? Saint Robert says that Blaserna did not consider the ablation of a glacier. When the extension of a glacier is constant, annual ablation is exactly equal to the amount of snow falling at the top every year. A glacier, increases or decreases from one year to another depending on whether the ablation is less than or greater than the amount of snow fall. But what is the cause of receding of glaciers? Saint Robert says that the main cause is the progressive decrease of precipitation during the cold season and the increase of summer temperature. The condensed water vapour at the top during the hot season, does not contributes to the formation of glaciers. The water vapour condensed during the cold season remains on the mountains in a state of snow and feeds the glaciers. At the same time, higher summer temperatures contribute to glacier retreat, increasing the ablation's erosion work. The weather observations in Turin, Geneva, Paris and San Bernardo, show, compared to 50/60 years earlier, a significant decrease in rainfall during the cold season and an increase of summer temperatures. These two conditions were caused, as Saint Robert says, by continuous deforestation of mountains and plains, and by the drainage works of rivers, marshes and ponds. All these actions, operated by man, reduced the evaporating surface and the important water vapour effect on mitigating summer temperatures and winter solar irradiation.

The theory of Saint Robert, to explain the Ice Age, is that in prehistoric period the evaporating surface was greater than the current. As a consequence, the huge quantity of atmospheric water vapour reduced the temperature difference between the cold and the hot season, lowering the level of perennial snow. During the Ice Age the temperature of Europe, or at least the summer temperature, was lower than the current and that the cause of the receding of glaciers is not attributed to astronomical causes, as some scholars believed at that time, but simply caused by climate change, in part caused by human activities on the earth's surface.

\subsection{Saint Robert's Theory Today}

Luca Mercalli, contemporary glaciologist, climatologist and meteorologist, supports that Saint Robert is certainly more acute than Blaserna when he excludes categorically that a glaciation can be the result of an increase of temperature, identifying correctly glacial conditions as the result of a decrease of temperature (today we know $6^{\circ} \mathrm{C}-10^{\circ} \mathrm{C}$ lower than the current). It's absolutely correct the interpretation of the glacial dynamics (today we call it mass balance) that is the balance between incoming snowfall on the glacier and ablation of ice during the summer.

Saint Robert incurs, however, in a series of inevitable mistakes due to the lack of systematic studies and of a complete database that would have allowed him a correct analysis. He makes a mistake when he doesn't consider the astronomical causes for the decrease of temperature. Joseph Alphonse Adhémar (1797-1862), an eminent French mathematician, was the first to propose in 1842 a rigorous scheme of astronomical forces that control the Earth's orbit and the glacial cycles. Adhémar theory was implemented in 1875 by James Croll (18211890). In the theory, still relevant today, exposed in 1941 by Milutin Milankovitch (1879-1958) it's demonstrated how some orbital parameters, as for example the eccentricity of Earth's orbit around the sun, the tilt of the Earth and the procession of equinoxes change periodically, influencing the amount of incoming solar radiation on Earth and therefore changing the climate.

Saint Robert's theory also does not consider the general atmospheric circulation and its synoptic variations to explain the decrease of winter precipitation. The cause of this decrease isn't due to local deforestation (as suggested by Saint Robert) because the true evaporating surface is not local, but rather represented by the Atlantic Ocean and the Mediterranean Sea. Saint Robert didn't have enough data to identify the mechanisms that lead European and alpine climatology and that control the advection of moisture in the Alps. The provisions of the atmospheric currents, on hemispheric scale, govern the alpine rainfall/snowfall by random or cyclic fluctuations, linked to oceanic currents or to changing in atmospheric pressure. Human activity was also a negligible cause on the climate change, because during 19th century the global population was only 2 billions (while today is 7 billions) and the use of fossil fuels was limited. The only consequences of deforestation operated by man, was hydrogeological instability in mountain regions. The retreat of glaciers, observed at the end of 1800 is not due to human activities but to the end of the Little Ice Age (1300-1850), caused both by a partial decrease in solar activity (Maunder's Minimum) and to a particular frequency of volcanic explosions that projected into the atmos- 
phere large quantities of dust, decreasing solar radiation, temperature and increasing precipitations (Mercalli, 2009).

\section{The True Meaning of a Tercet of Dante}

\subsection{Purpose and Explanation of Paul de Saint Robert}

The Count Paolo Ballada of Saint Robert wrote a memorandum with the intention of clarifying and providing the right interpretation of the thought of Dante on one of the most controversial and debated passages of the Divine Comedy. The memorandum The True Meaning of a Tercet of Dante presented in June 1866 at the Academy of Sciences of Torino refers to I chant of the Purgatory, wherein the Poet refers to a well specified astronomic phenomenon:

To the right hand I turned, and fixed my mind

Upon the other pole, and saw four stars

Ne'er seen before save by the primal people ${ }^{5}$.

Dante knew very well Astronomy, affirms the Count of Saint Robert and this is demonstrated by the fact that in the Divine Comedy there are numerous astronomical allusions. Without the help of the Astronomy many passages of the Divine Comedy cannot be interpreted correctly.

Even if commentators identify the four stars forming the Southern Cross as the stars to which Dante refers, this does not explain how Dante, who was born in 1265 and wrote his masterpiece at the beginning of 14th century, could have known a constellation that was not visible at that time from any known land, until the beginning of the sixteenth century by the first daring sailors.

Owing to the lack of a satisfactory explanation, the commentators had to refer to the allegory, defining that the Poet wanted to symbolize the four Cardinal Virtues: Prudence, Justice, Fortitude, Temperance and that only by chance they correspond to the truth, by connecting the meaning of the words "save by the primal people" to the fact that they were both honored by the ancients and then almost forgotten and ignored.

According to Saint Robert, the habit of using allegory in order to explain the difficulties encountered in the Divine Comedy is contrary to the intention of the author. As a matter of fact, the poet warns us in the Convivio that "[...] first much always be the literal sense, because it contains the other senses, otherwise you cannot understand it and especially the allegorical one" (Alighieri, 1928: Tome II, Chap I). Saint Robert then says that when Dante speaks of the "four stars ne'er seen before save by the primal people” (Alighieri, 1960: Purgatory I, v24) he refers to stars actually existing and not only in the imagination, and according to the words of Dante, he literally provides the scientific meaning.

Due to the attraction of the sun and moon on the equatorial bulge of the earth, the axis of this latter, instead of remaining parallel to itself, has a slow conical motion from east to west around the axis of the ecliptic, taking about 26,000 years to describe the entire cone. By changing the tilt of the earth with respect to the stars, consequently also changes the position of the horizon of each site in relation to them, other new stars become visible, whereas others become invisible.

This phenomenon is called precession of the equinoxes, because it anticipates the equinox every year of twenty minutes and a half. In this phenomenon we find the solution of the problems of understanding the words of Dante. Because of this motion of revolution of the earth's axis forty centuries ago the Southern Cross shone in our northern sky. Dante, says Saint Robert, certainly knew this movement almost imperceptible, because it also deals with it in chapter XV of the Treaty II of the Convivio, which describes the movement of the starry sphere almost insensitive about one degree in one hundred years. In more recent modern times, this value was corrected to about one degree every 72 years. Dante, continues Saint Robert, certainly well knew the existence of the four stars, as they are described in the catalogue (Almagest) of Ptolemy (100 - 178), where they do not form a specific constellation but are united in the Centaurus (Delambre, 1817).

The astrological address followed by Dante in his masterpiece is undoubtedly the scientific one which is headed by Claudius Ptolemy. Moreover, Ptolemy is mentioned several times (Ceri, 2000) in the Convivio by Dante, along with a clear understanding of his theories (Alighieri, 1928: Tome II, Chap III, XIV, XV).

\subsection{The Opinion of Other Scholars}

Orengo, Rinaldo (1895-1991) writes in his book Dante Man of Science (1978): “The Astronomy of Dante in the

${ }^{5}$ Alighieri, 1960: Purgatory I, v 22-24. 
Divine Comedy and in the Convivio, is not whimsical or fanciful: it is exact”. Dante had the possibility to know the doctrines handed down by the Almagest, which was translated in 1175 from Arabic into Latin by Gerard of Cremona (1114-1187) and he also had the possibility to know the work of Alfragano (c IX), De Aggregation Scientiae Stellarum (Moore, 1903) also mentioned in the Convivio (Alighieri, 1928: Tome II, Chap VI).

Corrado Gizzi (1915-2012) in his book Astronomy in the Sacred Poem (1974) admits that the entire cosmology of the Comedy has been built by the great Poet, on the precession of the equinoxes.

Even Alexander Humboldt (1769-1859) in his Examen Critique (1837) and in Cosmos (1848), writes Saint Robert, attributes a real existence to the four stars of Dante, but explains, as many commentators, that the words "ne'er seen before save by the primal people" (Alighieri, 1960: Purgatory I, v24) mean that they were only seen from Adam and Eve. At the time of Ptolemy, around the second century of the Christian era, they were still visible in the most southern parts of the Mediterranean, so it is no wonder that they were known to him and are included in its catalog. Consequently, these invisible stars in Europe at the time of Dante were visible, due to the precession of the equinoxes, to the early inhabitants of Europe, from the primal people.

It seems inexplicable to Saint Robert that Humbolt did not notice that the first people had to see the Southern Cross also living in the northern hemisphere. For him the first to suggest that the words "ne'er seen before save by primal people" (Ibidem) allude to the effect of the precession of the equinoxes, was the astronomer Littrow, Joseph Johann (1781-1840) in his book The Wonders of the Sky published in 1834. Even the astronomer Capocci, Ernesto (1798-1864) in his Cosmographic Illustrations of the Divine Comedy published in 1856 also admits the same explanation and confirms that Dante could be very well aware of the existence of the four stars because he knew the catalog of Ptolemy.

\subsection{Astronomer Zanotti Bianco on St Robert's Work}

Astronomer Zanotti Bianco Ottavio (1852-1932) in his Astrology and Astronomy (1905) writes: There is no shortage in these verses of the commentaries: maybe there are too much of them. Commentators have worked using their imagination, as usual, copying each other serious errors, ignoring as well the serious work of astronomers and the warnings of Dante himself. Two Italians astronomically employed these tercets, and their names are completely ignored, as their work by dantologi. I want to talk about Ernesto Capocci and Count Paolo Ballada de Saint Robert. The first is a Neapolitan astronomer, who in 1856 published a book entitled Cosmographic Illustrations of the Divine Comedy. The second is a distinguished mathematician who cultivated science not for earning a living but for pure love. He left lasting traces in various branches of knowledge, he published a work entitled The true meaning of a tercet of Dante. In both works there is the correct explanation of verses 22 24 of chant I of Purgatory.

Saint Robert in stating that the "four stars ne'er seen before save by primal people” (Alighieri, 1960: Purgatory I, v24) actually exist and are those of the Southern Cross, also asserts that Dante could have known those stars because he had studied and meditated about the Treaty of Ptolemy, although they were long ago disappeared from the horizon of any place in Italy due to the precession of the equinoxes. But the explanation of Saint Robert was totally ignored, as well as that of Littrow and Ernesto Capocci.

\subsection{Paul de Saint Robert's Scientific Proof}

Saint Robert in the conclusion of his memory consolidates the astronomical theories contained in the tercet of Dante with a clear graphical representation, obviously supported by mathematical calculations. Table 1 is taken from his memorandum; Saint Robert shows the results of his calculations for the declination and adding the complement of the latitude of $45^{\circ}$ obtain the height of $\alpha$ Southern Cross and Sirius on the horizon related to a point located at $45^{\circ}$ north latitude (Central Europe), in the period between 13,000 years before Christian era, and 13,000 years after Christian era.

From the graph (Figure 1) of Saint Robert, it can be inferred that $\alpha$ of the Southern Cross began to be invisible from the "primal people" at a latitude of $45^{\circ}$ (Central Europe) 1410 years before the Christian era. It will make itself visible again in the year 12,293, and will remain so for 12,062 years before returning invisible for other 13,703 years. The same goes for the star Sirius which nowadays is one of the most beautiful stars in our sky: it will become invisible in the year 9118 and will not reappear on the horizon until after other 9505 years, thus remaining visible over the centuries for 16,260 years and invisible for 9505 years. 
Table 1. Declination and height on the horizon ${ }^{6}$.

\begin{tabular}{|c|c|c|c|c|}
\hline Years & $\begin{array}{l}\text { Southern } \\
\text { Cross } \alpha \\
\text { A }\end{array}$ & $\begin{array}{c}\text { Sirius } \\
\text { A }\end{array}$ & $\begin{array}{c}\text { Southern } \\
\text { Cross } \alpha \\
\text { B }\end{array}$ & $\begin{array}{c}\text { Sirius } \\
\text { B }\end{array}$ \\
\hline$-13,000$ & $-42^{\circ} 49^{\prime}$ & $-61^{\circ} 39^{\prime}$ & $+2^{\circ} 11^{\prime}$ & $-16^{\circ} 39^{\prime}$ \\
\hline$-11,000$ & $-35^{\circ} 9^{\prime}$ & $-62^{\circ} 7^{\prime}$ & $+9^{\circ} 51^{\prime}$ & $-17^{\circ} 7^{\prime}$ \\
\hline-9000 & $-30^{\circ} 31^{\prime}$ & $-54^{\circ} 52^{\prime}$ & $+14^{\circ} 29^{\prime}$ & $-9^{\circ} 52^{\prime}$ \\
\hline-7000 & $-29^{\circ} 29^{\prime}$ & $-44^{\circ} 12^{\prime}$ & $+15^{\circ} 31^{\prime}$ & $+0^{\circ} 48^{\prime}$ \\
\hline-5000 & $-32^{\circ} 9^{\prime}$ & $-33^{\circ} 24^{\prime}$ & $+12^{\circ} 51^{\prime}$ & $+11^{\circ} 36^{\prime}$ \\
\hline-3000 & $-38^{\circ} 12^{\prime}$ & $-24^{\circ} 17^{\prime}$ & $+6^{\circ} 48^{\prime}$ & $+20^{\circ} 43^{\prime}$ \\
\hline-1000 & $-46^{\circ} 59^{\prime}$ & $-18^{\circ} 13^{\prime}$ & $-1^{\circ} 59^{\prime}$ & $+26^{\circ} 47^{\prime}$ \\
\hline Christian Era & $-52^{\circ} 7^{\prime}$ & $-16^{\circ} 37^{\prime}$ & $-7^{\circ} 7^{\prime}$ & $+28^{\circ} 23^{\prime}$ \\
\hline+1000 & $-57^{\circ} 2^{\prime}$ & $-16^{\circ} 5^{\prime}$ & $-12^{\circ} 2^{\prime}$ & $+28^{\circ} 55^{\prime}$ \\
\hline+3000 & $-68^{\circ} 6^{\prime}$ & $-18^{\circ} 16^{\prime}$ & $-23^{\circ} 6^{\prime}$ & $+26^{\circ} 44^{\prime}$ \\
\hline+5000 & $-75^{\circ} 58^{\prime}$ & $-24^{\circ} 22^{\prime}$ & $-30^{\circ} 58^{\prime}$ & $+20^{\circ} 38^{\prime}$ \\
\hline+7000 & $-72^{\circ} 38^{\prime}$ & $-33^{\circ} 30^{\prime}$ & $-27^{\circ} 38^{\prime}$ & $+11^{\circ} 30^{\prime}$ \\
\hline+9000 & $-62^{\circ} 26^{\prime}$ & $-44^{\circ} 20^{\prime}$ & $-17^{\circ} 26^{\prime}$ & $+0^{\circ} 40^{\prime}$ \\
\hline+11000 & $-51^{\circ} 33^{\prime}$ & $-54^{\circ} 58^{\prime}$ & $-6^{\circ} 33^{\prime}$ & $-9^{\circ} 58^{\prime}$ \\
\hline
\end{tabular}

Note: $\mathrm{A}=$ Declination; $\mathrm{B}=$ Height on the horizon .

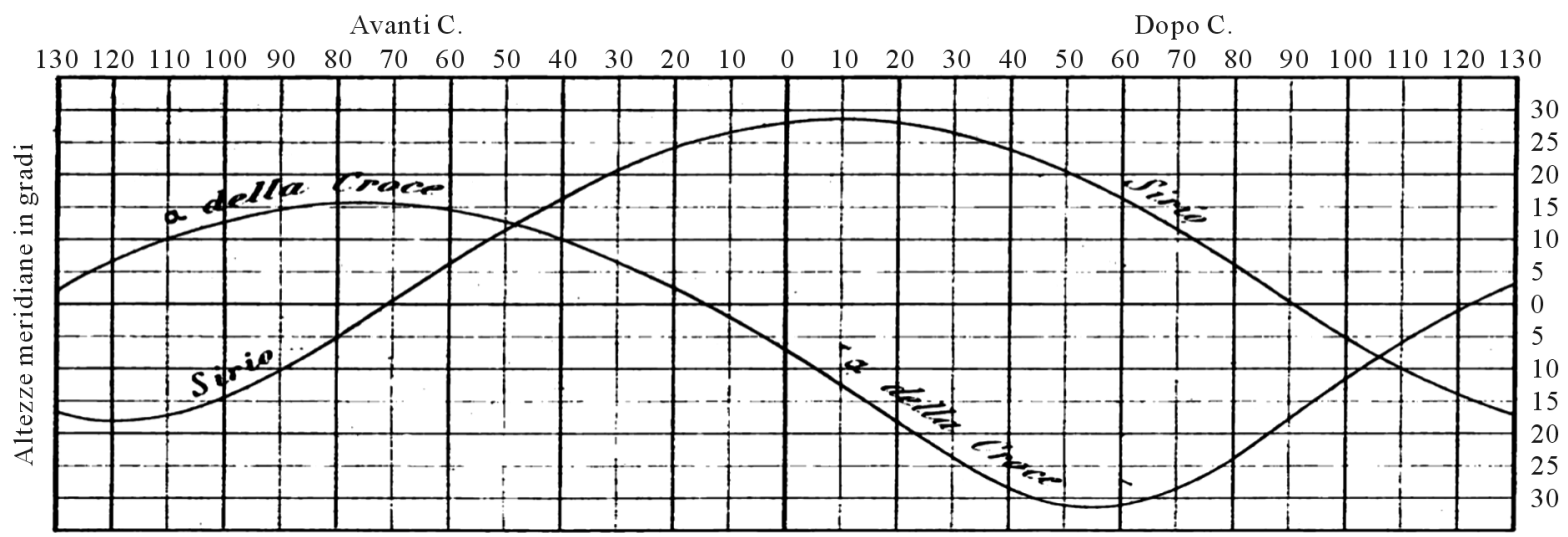

Figure 1. The position over the centuries of the two stars for $45^{\circ}$ north latitude ${ }^{7}$.

\section{Conclusion}

We think that it is useful to propose the two notes to better understand the scientific approach, the intellectual honesty and promotion of scientific culture of this great character, mostly forgotten in the history's folds.

About the first note, it's important to remember that the Italian Glaciological Committee (the first scientific approach to glaciology in Italy) was founded in 1895 twelve years later than Saint Robert's theory about receding of glaciers. The Count tried, with more than a century in advance and despite the limited knowledge of its historical period, to outline problems that would have prevailed only in more recent times.

About the second note, even today the verse "ne'er seen before by the primal people" (Alighieri, Purgatory I, v24) is the subject of conflicting discussion and argument among scholars of Dante, but we think that tying the

\footnotetext{
${ }^{6}$ Adapted: Saint Robert, 1865-1866: I, pp. 598-601.

${ }^{7}$ Ibidem.
} 
proven and documented knowledge of Dante in the field of astronomy to the mathematical and scientific proof of Saint Robert, there is no reason to interpret in a different way the words of Dante.

\section{References}

Alighieri, D. (1928). Il Convivio. Con note di F. Cavazzoni Pederzini. Tipografia Camerale, Modena, T II, Chaps I, III, VI, XIV, XV.

Alighieri, D. (1960). Divine Comedy. Purgatory I. Testo critico della Società Dantesca Italiana. Milano: Hoepli.

Bianco, O. Z. (1905). Astrologia e Astronomia: Saggi di Astronomia. Torino: Bocca, 102-137.

Blaserna, P. (1882-1883). Sulla temperatura corrispondente al periodo glaciale. 17 Giugno 1883. Atti della Reale Accademia dei Lincei, Transunti, s3, fasc. 14. Vol. VII, Roma: Coi Tipi del Salviucci, 284-287.

Blaserna, P. (1883-1884a). Sulla temperatura corrispondente al periodo glaciale. Nota 2/16. Dicembre 1883. Atti della Reale Accademia dei Lincei, Transunti, s3, fasc. 1. Vol. VIII, Roma: Coi Tipi del Salviucci, 79-81.

Blaserna, P. (1883-1884b). Sulla temperatura corrispondente al periodo glaciale. Nota 3/3 e 4 Febbraio 1884, Atti della Reale Accademia dei Lincei, Transunti, s3, fasc. 1. Vol. VIII, Roma: Coi Tipi del Salviucci, 101-103.

Capello, C. F. (1930). Bibliografia glaciologica italiana, I. 1928. Bollettino del Comitato Glaciologico Italiano 10. Torino: Tipografia Sociale Torinese, 287.

Capocci, E. (1856). Illustrazioni Cosmografiche della Divina Commedia. Napoli: Stamperia dell’Iride, 38-48, 65-69.

Ceri, G. (2000). La precessione degli Equinozi in Dante. Sotto il Velame, 1, 6-34.

Crivellaro, P. (1998). Quintino Sella Una Salita al Monviso. Verbania: Tararà.

De Marchi, L. (1911). Nuove teorie sulle cause dell'era glaciale. Scientia. Rivista internazionale di sintesi scientifica, 5-6, 310-328.

Delambre, J. B. J. (1817). Histoire de l’Astronomie Ancienne. Vol. 2, Paris: Courcier, 282.

Drago, A .(1993). Forza ed Energia l’Analisi Critica di Saint Robert. Quaderni PRISTEM, 4, 91-113.

Gillispie, C. C., \& Pisano, R. (2014). Lazare and Sadi Carnot. A Scientific and Filial Relationship (2nd ed.). Dordrecht: Springer. http://dx.doi.org/10.1007/978-94-017-8011-7

Gizzi, C. (1974). L’Astronomia nel Poema Sacro. Napoli: Loffredo.

Humboldt, A. (1837). Examen Critique. Tome IV. Paris: Libraire Gide, 321-333.

Humboldt, A. (1848). Cosmos: The Physical Phenomena of the Universe. Vol. 2, London: Hippolyte Bailliere Publisher, 325-331.

Littrow, J. J. (1834). Die Wunder des Himmels. Stuttgart: Hoffman.

Maffioli, F., \& Medici, G. (2013). Physics, Astronomy and Engineering. Critical Problems in the History of Science. Proceedings of the 32th International Congress of the Italian Society of Historians of Physics and Astronomy, Šiauliai: The Scientia Socialis Press, 313-319.

Malaroda, R. (1995). Cento anni di ricerca glaciologica in Italia. Atti del VII Convegno del Comitato Glaciologico Italiano (Torino, 19-20 Ottobre 1995). Geografia Fisica e Dinamica Quaternaria, 18, 159-162.

Medici, G., \& Maffioli, F. (2013). Physics, Astronomy and Engineering. Critical Problems in the History of Science. Proceedings of the 32nd International Congress of the Italian Society of Historians of Physics and Astronomy, Šiauliai: The Scientia Socialis Press, 329-336.

Mercalli, L. (2009). Che tempo che farà. Breve storia del clima con uno sguardo al futuro. Rizzoli, Milano.

Moore, E. (1903). Studies in Dante, Third Series. Oxford: The Clarendon Press, 3.

Orengo, R. (1978). Dante Uomo di Scienza (2 ed.). Sanremo: Mizar, 24-32.

Perkins Marsh, G. (1870). L'uomo e la natura. Ossia la superficie terrestre modificata per opera dell'uomo. Firenze: Barbèra editore.

Pisano, R. (2007). Note sui Principes de Thermodynamique di Paul de St Robert. Proceedings of 24th SISFA Congress, Napoli: Bibliopolis, 129-134.

Pisano, R. (2014). On a Comparative Analysis between Paul de Saint-Robert's Principes de thermodynamique (1865) and Sadi Carnot’s Réflexions sur la puissance motrice du feu (1824) Theory. Gillispie and Pisano 2014, 31-57.

Pisano, R., Capecchi, D., \& Lukešová, A. Eds. (2013). Physics, Astronomy and Engineering. Critical Problems in the History of Science. Proceedings of the 32th International Congress of the Italian Society of Historians of Physics and Astronomy, Šiauliai: The Scientia Socialis Press. 
Redondi, P. (1974-1975). Contributi alla Conoscenza di S. Carnot e dei Principi della Termodinamica di Paul de St Robert. Accademia delle Scienze, 281-318.

Sacco, F. (1927). Gli studi glaciologici in Italia. Roma: Consiglio Nazionale delle Ricerche, Comitato Geodetico e Geofisico-Sezione per l’Idrogeologia Scientifica, 129-134.

Saint Robert, P. (1865) Principes del Thermodynamique. Torino: J. Cassone.

Saint Robert, P. (1865-1866). Sul vero significato di una terzina di Dante. Atti della Reale Accademia delle Scienze di Torino, 1, 588-601.

Saint Robert, P. (1867). Gita al Monte Ciamarella nelle Alpi Graie. Bollettino trimestrale del Club Alpino Italiano, 10-11, 243-264.

Saint Robert, P. (1868-1869). Notice biographique sur Sadi Carnot. Atti della Reale Accademia delle Scienze di Torino, 4, 151-170.

Saint Robert, P. (1870). Principes de Thermodynamique (2nd ed.). Torino: Loescher.

Saint Robert, P. (1872-1874). Mémoires Scientifiques réunis mise en ordre. Torino: Bona.

Saint Robert, P. (1883-1884). Perché i ghiacciai si vadano ritirando. 2 Dicembre 1883. Atti della Reale Accademia dei Lincei, Transunti, s3, fasc. 1. Vol. 8, Roma: Coi Tipi del Salviucci, 56-62.

Stoppani, A. (1880-1881). Sul regresso dei ghiacciai alpini. 12 giu. 1881, Atti della Accademia Pontificia de'Nuovi Lincei, annata 34, tomo 34. Roma: Tipografia delle Scienze Matematiche e Fisiche, 482-484. 
Scientific Research Publishing (SCIRP) is one of the largest Open Access journal publishers. It is currently publishing more than 200 open access, online, peer-reviewed journals covering a wide range of academic disciplines. SCIRP serves the worldwide academic communities and contributes to the progress and application of science with its publication.

Other selected journals from SCIRP are listed as below. Submit your manuscript to us via either submit@scirp.org or Online Submission Portal.
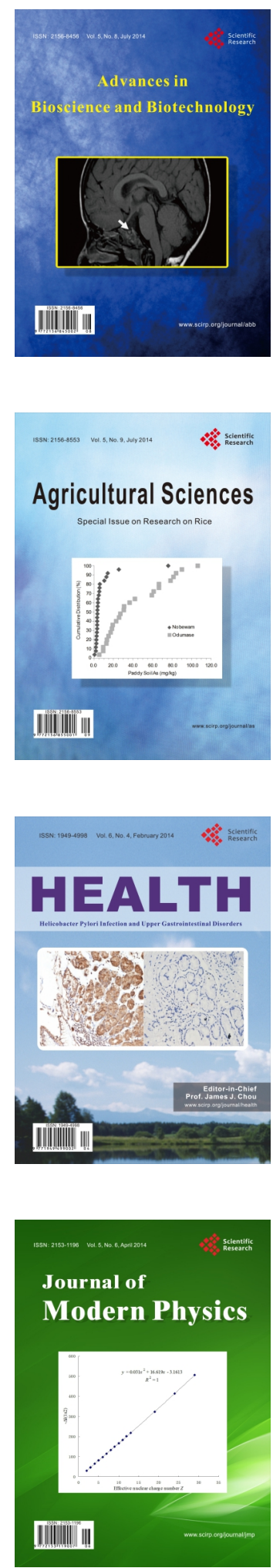
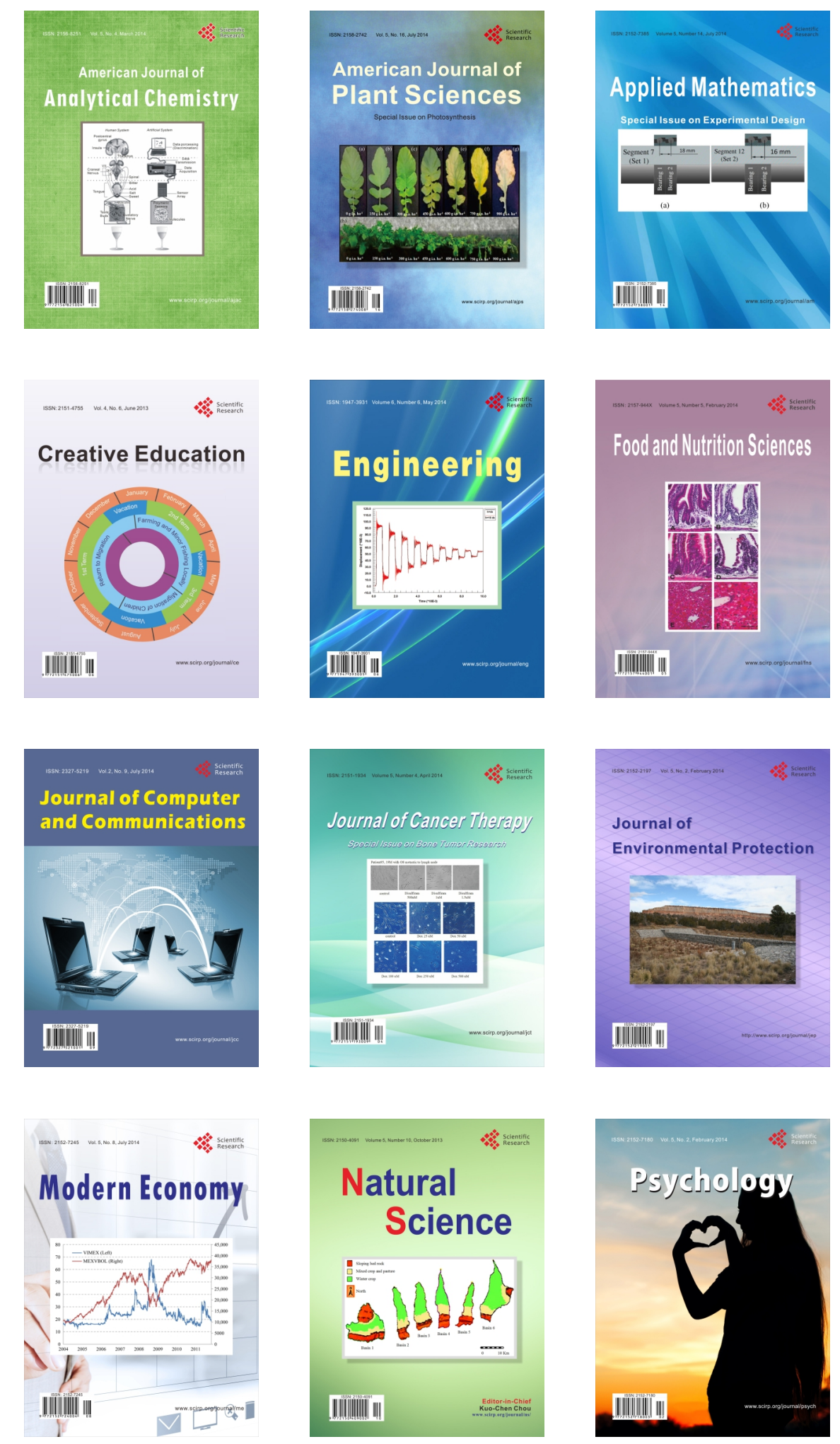